\title{
COVID-19 encephalopathy: an unusual presentation with new-onset seizure causing convulsive status epilepticus
}

\author{
Aisha Fareed Siddiqui @ , Sheema Saadia, Taymmia Ejaz, Zain Mushtaq
}

Section of Internal Medicine, Department of Medicine, The Aga Khan University Hospital, Karachi, Pakistan

\section{Correspondence to}

Dr Zain Mushtaq;

zain.mushtaq@aku.edu

Accepted 10 February 2022

Check for updates

(c) BMJ Publishing Group Limited 2022. No commercial re-use. See rights and permissions. Published by BMJ.

To cite: Siddiqui AF, Saadia S, Ejaz T, et al. BMJ Case Rep 2022;15:e245387. doi:10.1136/bcr-2021245387

\section{SUMMARY}

Although neurological manifestations such as headache and myalgias have been observed with COVID-19, presentation with more serious neurological illness is uncommon and rare. We report a case of a middle-aged woman who presented to the emergency department of a tertiary care hospital. Her clinical presentation was primarily neurological rather than the more common presentation with respiratory manifestations. She presented with generalised tonic-clonic seizures, along with history of undocumented low-grade fever and generalised body aches. The positive SARS-CoV-2 RT-PCR nasal swab, the cerebrospinal fluid analysis (lymphocytic pleocytosis) and electroencephalogram were consistent with viral encephalitis; brain imaging was unremarkable. This case highlights the variable presenting features of COVID-19 infection as patients can primarily present with neurological manifestations in the absence of significant respiratory symptoms. We believe it is important to recognise neurological disease associated with SARS-CoV-2 in patients with asymptomatic respiratory infection.

\section{BACKGROUND}

As of 2 December 2021, during the COVID-19 pandemic, there have been 264 million cases of novel SARS-CoV-2 and the pandemic has resulted in 5.23 million deaths worldwide. ${ }^{12}$ It is gradually being recognised that COVID-19 can present with neurological manifestations in the absence of the usual respiratory symptoms. These neurological manifestations of COVID-19 are common and can be observed in up to $36.4 \%$ of patients. ${ }^{23}$ Several theories proposed include the passage of virus through the blood-brain barrier following viraemia, SARS-CoV-2 binding to the ACE receptor type 2 (ACE-2) cells in brain vascular endothelium and post viral autoimmune process along with metabolic and systemic complication of the disease. The olfactory bulb is the most accepted plausible route of the virus to the brain. ${ }^{24}$ The more common neurological manifestations of COVID-19 include headache, anosmia, ageusia and myalgia/myositis. ${ }^{2} 45$ Rare complications have been reported and include cases of acute cerebrovascular disease, encephalitis and encephalopathy, Guillain-Barre syndrome and haemophagocytic lymphohistiocytosis. The incidence of these complications ranges from $6 \%$ to $36 \% .^{6}$ As the COVID-19 pandemic has progressed, varied manifestation of the disease, that is, respiratory, gastrointestinal, neurological and cardiac, has been observed. Physicians should anticipate neurological manifestations as an initial presenting feature in patients with COVID-19. We hereby report a case of COVID-19 encephalitis in which generalised tonic-clonic seizures were the presenting feature of the disease. To our knowledge, this is the first reported case of COVID-19 encephalitis with CSF (cerebrospinal fluid) analysis, brain imaging and EEG (electroencephalogram) findings in Pakistan.

\section{CASE PRESENTATION}

A middle-aged woman presented to the emergency department of a tertiary care hospital with an episode of generalised tonic-clonic seizures at home. It lasted for $60 \mathrm{~min}$, all four limbs became rigid along with up-rolling of the eyes, frothing from mouth; however, no tongue biting or urinary incontinence was seen. She also had a history of (undocumented) low-grade fever, body aches, along with diarrhoea 3 days ago. Her medical history revealed that she had diabetes mellitus and central diabetes insipidus and was taking tablet sitagliptin/metformin $50 / 500 \mathrm{mg}$ (once daily) and desmopressin $0.2 \mathrm{mg}$ (at bedtime) as her home medication. She had no recent history of contact with a COVID-19 positive person or any visit to a public place. There was no history of smoking, addictions or substance abuse such as opium use. Physical examination revealed that she was afebrile, blood pressure was $141 / 100$ $\mathrm{mmHg}$, heart rate was 90 beats/min, respiratory rate 20 breaths/min and oxygen saturation was $88 \%$ on room air. The airway was patent. No cyanosis or sweating was seen. Neurological examination revealed an acutely confused state, GCS score (Glasgow Coma Scale) was 13/15 (eye opening-4; verbal-3; motor-6); there was spontaneous eye opening, she was unresponsive to painful stimulus and all four limbs were rigid. Examination of the cranial nerves was unremarkable. Her pupils were bilaterally equally reactive to light with no asymmetry. Motor examination including tone, power, tendon reflexes showed bilateral upper limbs flexed and rigid. Coordination was difficult to assess at this time. Minimal neck stiffness was present. No nystagmus or pronator drift was evident. Chest auscultation revealed crepitation on the right side of the chest. The cardiovascular and abdominal examination was unremarkable.

\section{INVESTIGATIONS \\ Blood samples}

Complete blood count showed a normocytic, normochromic picture. Serum creatinine and 
Table 1 Initial baseline laboratory workup and investigations

\begin{tabular}{|c|c|}
\hline \multicolumn{2}{|c|}{ Laboratory investigations at admission } \\
\hline \multicolumn{2}{|l|}{ Complete blood count } \\
\hline Haemoglobin & $114 \mathrm{~g} / \mathrm{L}$ \\
\hline Haematocrit & $36.40 \%$ \\
\hline White cell count & $6.3 \times 10^{9} / \mathrm{L}$ \\
\hline Neutrophils & $71 \%$ \\
\hline Lymphocytes & $21.50 \%$ \\
\hline Platelets & $340 \times 10^{9} / \mathrm{L}$ \\
\hline \multicolumn{2}{|l|}{ Biochemical analysis } \\
\hline Blood urea nitrogen & $13 \mathrm{mg} / \mathrm{dL}$ \\
\hline Creatinine & $1.5 \mathrm{mg} / \mathrm{dL}$ \\
\hline Glomerular filtration rate & $37.11 \mathrm{~mL} / \mathrm{min} / 1.73 \mathrm{~m}^{2}$ \\
\hline Sodium & $138 \mathrm{mEq} / \mathrm{L}$ \\
\hline Potassium & $3.9 \mathrm{mEq} / \mathrm{L}$ \\
\hline Chloride & $101 \mathrm{mEq} / \mathrm{L}$ \\
\hline Bicarbonate & $20.4 \mathrm{mEq} / \mathrm{L}$ \\
\hline Magnesium & $2.5 \mathrm{mg} / \mathrm{dL}$ \\
\hline Calcium & $9.1 \mathrm{mg} / \mathrm{dL}$ \\
\hline \multicolumn{2}{|l|}{ Liver function tests } \\
\hline Total bilirubin & $0.4 \mathrm{mg} / \mathrm{dL}$ \\
\hline Direct bilirubin & $0.1 \mathrm{mg} / \mathrm{dL}$ \\
\hline Indirect bilirubin & $0.3 \mathrm{mg} / \mathrm{dL}$ \\
\hline Gamma-glutamyl transferase & $61 \mathrm{IU} / \mathrm{L}$ \\
\hline Alanine aminotransferase & $14 \mathrm{IU} / \mathrm{L}$ \\
\hline Alkaline phosphatase & $86 \mathrm{IU} / \mathrm{L}$ \\
\hline Aspartate aminotransferase & $12 \mathrm{IU} / \mathrm{L}$ \\
\hline \multicolumn{2}{|l|}{ Inflammatory markers } \\
\hline C-reactive protein & 39.17 \\
\hline Lactate dehydrogenase & $228 \mathrm{IU} / \mathrm{L}$ \\
\hline Ferritin & $70.2 \mathrm{ng} / \mathrm{mL}$ \\
\hline D-dimer & $1.0 \mathrm{mg} / \mathrm{L} \mathrm{FEU}$ \\
\hline Procalcitonin & $0.08 \mathrm{ng} / \mathrm{mL}$ \\
\hline \multicolumn{2}{|l|}{ Coagulation profile } \\
\hline Prothrombin time & $10.1 \mathrm{~s}$ \\
\hline International Normalized ratio & 1 \\
\hline Partial thromboplastin time & $27 \mathrm{~s}$ \\
\hline \multicolumn{2}{|l|}{ Arterial blood gas } \\
\hline $\mathrm{pH}$ & 7.39 \\
\hline $\mathrm{PCO}_{2}$ & $32.7 \mathrm{~mm} \mathrm{Hg}$ \\
\hline $\mathrm{PO}_{2}$ & $53.4 \mathrm{~mm} \mathrm{Hg}$ \\
\hline Bicarbonate & $19.2 \mathrm{mEq} / \mathrm{L}$ \\
\hline Base excess & Negative $4.7 \mathrm{mEq} / \mathrm{L}$ \\
\hline $\mathrm{O}_{2}$ saturation & $86.40 \%$ \\
\hline Lactic acid & $5.6 \mathrm{mmol} / \mathrm{L}$ \\
\hline Creatinine phosphokinase levels & $623 \mathrm{IU} / \mathrm{L}$ \\
\hline Troponin I & $0.006 \mathrm{ng} / \mathrm{mL}$ \\
\hline Blood culture & No growth \\
\hline Serum glucose & $310 \mathrm{mg} / \mathrm{dL}$ \\
\hline \multicolumn{2}{|l|}{ Urine detailed report } \\
\hline Colour & Yellow \\
\hline Appearance & Clear \\
\hline Specific gravity & 1.015 \\
\hline $\mathrm{pH}$ & 6 \\
\hline Protein & Negative \\
\hline Glucose & Negative \\
\hline Ketones & Negative \\
\hline Haemoglobin & $150 / \mu \mathrm{L}(+4)$ \\
\hline
\end{tabular}

Table 1 Continued

\begin{tabular}{|c|c|}
\hline \multicolumn{2}{|c|}{ Laboratory investigations at admission } \\
\hline Nitrite & Negative \\
\hline Leucocyte esterase & Negative \\
\hline Bacteria & Nil \\
\hline COVID-19 nasopharyngeal swab & Positive \\
\hline
\end{tabular}

C-reactive protein levels were raised (table 1). Arterial blood gas indicated hypoxia. Serum D-dimer was $1.0 \mathrm{mg} / \mathrm{L}$ FEU, while serum ferritin and lactate dehydrogenase levels were normal. Serum creatinine phosphokinase levels were 623 (34-145) IU/L and lactate was $5.6 \mathrm{mmol} / \mathrm{L}$, indicating post-ictal elevation. On serial monitoring, lactate levels normalised. Procalcitonin levels were less than $0.5 \mathrm{ng} / \mathrm{mL}$, representing low risk for any localised bacterial infection and the blood culture also did not grow any organism as well.

\section{Nasal swab specimen}

Nasal swab for COVID-19 qualitative RT-PCR (real-time reverse-transcription PCR) was positive.

\section{Cerebrospinal fluid sample}

CSF detailed report (CSF DR) showed glucose 133 (40-70) $\mathrm{mg} / \mathrm{dL}$ (serum $260 \mathrm{mg} / \mathrm{dL}$ ), proteins $68 \mathrm{mg} / \mathrm{dL}(15-40)$ with lymphocytic pleocytosis (95\%). BioFire Film Array meningitis/ encephalitis panel was negative for 14 pathogens. This test uses a multiplex PCR assay for the detection of 14 common pathogens that can cause central nervous system (CNS) infections (table 2).

\begin{tabular}{|c|c|}
\hline \multicolumn{2}{|l|}{ Cerebrospinal fluid analysis } \\
\hline Glucose (40-70) & $133 \mathrm{mg} / \mathrm{dL}$ \\
\hline Chloride (122-132) & $139 \mathrm{mEq} / \mathrm{L}$ \\
\hline Protein $(15-40)$ & $68 \mathrm{mg} / \mathrm{dL}$ \\
\hline Total leucocyte count $(0-0.005)$ & $0.015\left(\times 10^{3} / \mu \mathrm{L}\right)$ \\
\hline Polymorphs (0-5) & $5 \%$ \\
\hline Lymphocytes & $95 \%$ \\
\hline Red blood cell & $0.001\left(\times 10^{6} / \mu \mathrm{L}\right)$ \\
\hline Pus cells & Rare \\
\hline Microorganisms & Nil \\
\hline India ink & Negative \\
\hline Culture & No growth \\
\hline \multicolumn{2}{|l|}{ BIO-FIRE FILM ARRAY PANEL } \\
\hline Escherichia coli K1 & Not detected \\
\hline Haemophilus influenzae & Not detected \\
\hline Listeria monocytogenes & Not detected \\
\hline Neisseria meningitidis & Not detected \\
\hline Streptococcus agalactiae & Not detected \\
\hline Streptococcus pneumoniae & Not detected \\
\hline Cytomegalovirus & Not detected \\
\hline Enterovirus & Not detected \\
\hline Herpes simplex virus 1 & Not detected \\
\hline Herpes simplex virus 2 & Not detected \\
\hline Human herpesvirus 6 & Not detected \\
\hline Human parechovirus & Not detected \\
\hline Varicella zoster virus & Not detected \\
\hline Cryptococcus neoformans/gattii & Not detected \\
\hline Biofire filmarray meningitis/encephalitis panel (BFM) culture & No growth \\
\hline
\end{tabular}




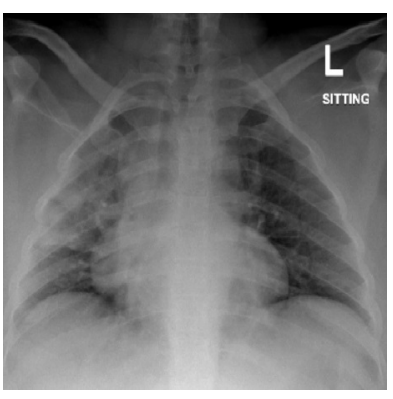

Figure 1 Chest X-ray showed inhomogeneous airspace shadowing involving the right lung upper and mid-zone.

\section{Imaging}

Chest X-ray showed inhomogeneous airspace shadowing involving the right lung upper and mid-zone, suggesting lobar consolidation and aspiration pneumonia (figure 1).

A CT scan of the head without contrast showed no established infarct, acute intracranial haematoma or mass effect, excluding a major structural cause of epilepsy (figure 2).

MRI of the brain showed normal grey and white matter differentiation, no acute infarction on Diffusion-weighted imaging (DWI), and no abnormal parenchymal enhancement on post contrast imaging, suggesting no epileptogenic foci (figure 3). Time of flight MR angiography images revealed normal anterior and posterior intracranial vasculature, with no high-grade stenosis or occlusion in major vessels.

Post contrast MR venography (MRV) showed no filling defect in the venous sinuses.

\section{Electrophysiological studies}

EEG showed slow posterior dominant rhythm (in theta range), as well as intermittent bilateral left anterior dominant and generalised rhythmic delta slow waves, suggesting mild encephalopathy (figure 4).

\section{DIFFERENTIAL DIAGNOSIS}

Considering the ongoing COVID-19 pandemic, other differential diagnoses were ruled out to make a diagnosis of COVID-19 encephalitis. Our patient did not have any electrolyte abnormalities. Her blood sugar level was in range, thereby eliminating hypoglycaemia. Her creatinine was mildly elevated, but she did not have any known renal disease, thereby ruling out uraemic encephalopathy. Therefore, the above-mentioned data ruled

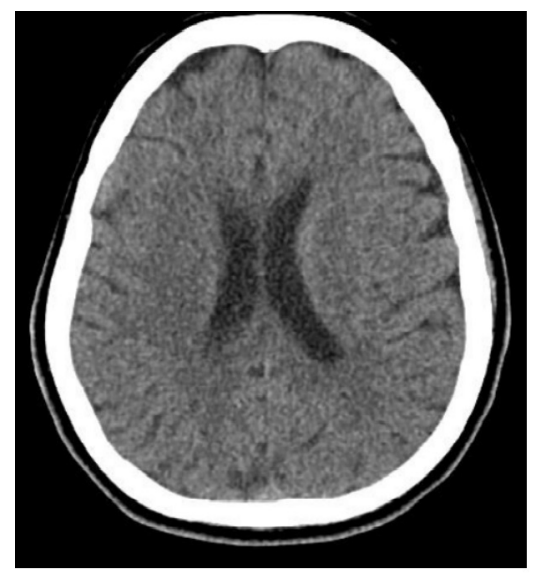

Figure 2 CT scan (head without contrast) was unremarkable.
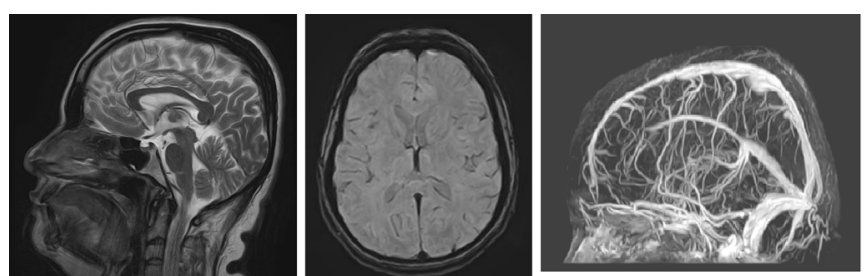

Figure 3 (A, B) MRI brain plain showed normal findings; (C) normal $M R$ venography.

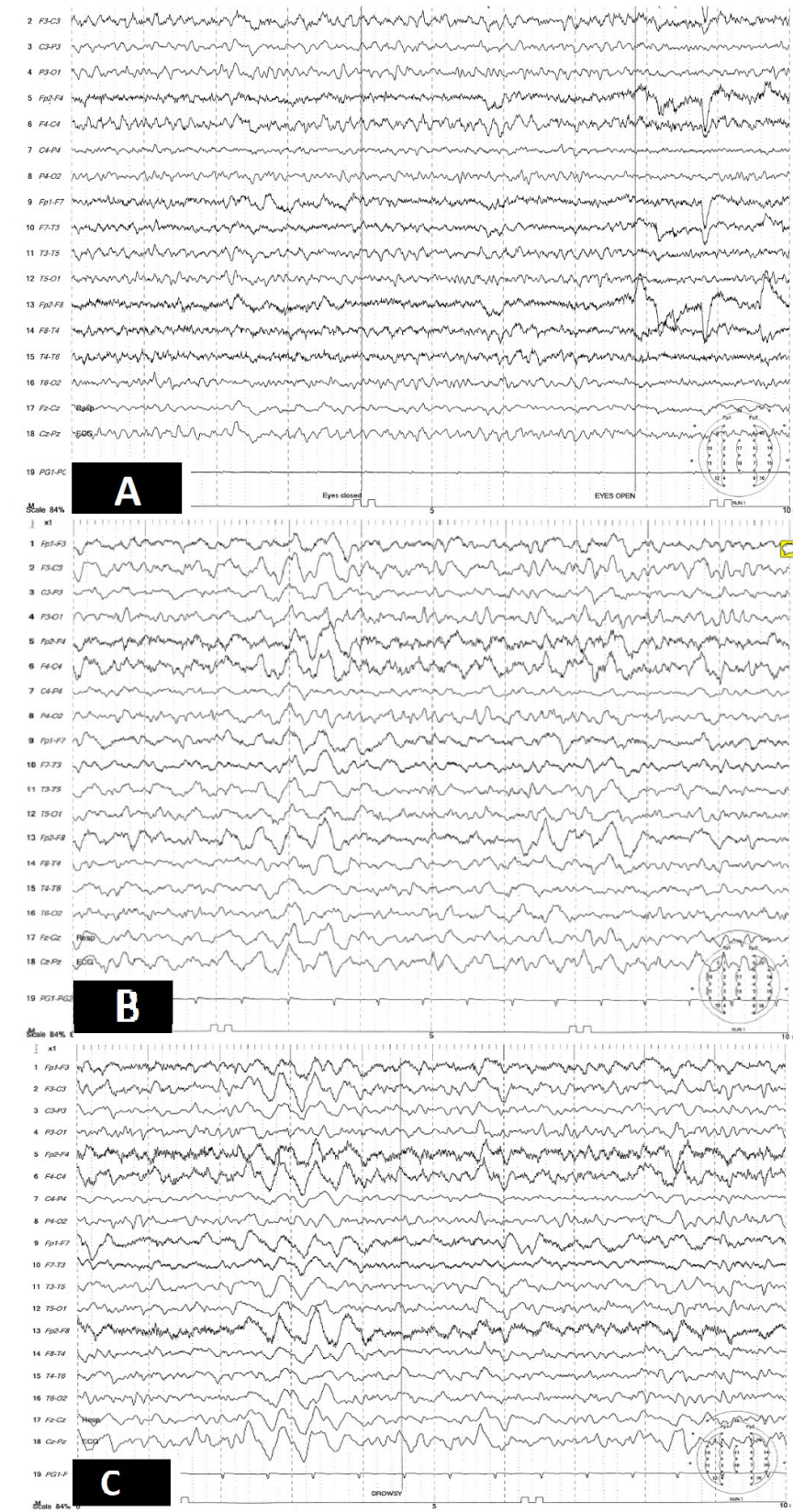

Figure 4 Electroencephalogram (EEG). (A) Epoch-A awake EEG in longitudinal bipolar montage which shows a slow posterior dominant rhythm in the theta range suggestive of mild encephalopathy. $(B, C)$ Epoch-B in longitudinal bipolar montage which shows diffuse slowing theta and delta burst waves (anterior dominant) either due to drowsy clinical state of the patient or antiepileptic drug use. 
out all metabolic causes of generalised tonic-clonic seizures resulting in convulsive status epilepticus. Anoxic encephalopathy was ruled out as the arterial blood gas did not show hypoxia significant enough to lead to a neurological injury. ECG was unremarkable, eliminating cardiogenic syncope leading to a secondary hypoxia. Later, neurovascular imaging showed no evidence of stroke or cerebral venous sinus thrombosis. Infective causes, that is, viral, bacterial and fungal causes, were looked into in the CSF DR as well as the Bio-Fire meningitis/encephalitis panel. The possibility of autoimmune encephalitis could not be excluded. Immunotherapy with steroids was started immediately, owing to the suspicion of meningitis and its complications. Furthermore, autoantibody tests such as NMDA (N-methylD-aspartate) receptor antibodies were not done as she did not have any related comorbidities ${ }^{7}$ and the symptoms resolved with conservative management.

\section{TREATMENT}

Our patient received her first aid in the emergency department. Primary care was initiated. Her airway was patent, supplemental oxygen given via face mask. Vitals were checked. Intravenous access was obtained, and blood samples were sent for analysis. Intravenous diazepam was given immediately. Intravenous paracetamol, ceftriaxone, vancomycin, acyclovir and dexamethasone were given along with intravenous Ringer's lactate for hydration. Intravenous injection of levetiracetam $1000 \mathrm{mg}$ and later $2 \mathrm{mg}$ intravenous midazolam and $1500 \mathrm{mg}$ intravenous phenytoin were also given. She was admitted in special care COVID-19 isolation unit and was managed on the lines of non-severe COVID-19 pneumonia with suspected meningoencephalitis. A lumbar puncture was performed and the CSF was sent for analysis. Antimicrobial therapy was continued on meningitic doses - intravenous ceftriaxone $2000 \mathrm{mg}$ two times per day, intravenous vancomycin $750 \mathrm{mg} 6$ hourly and intravenous acyclovir $750 \mathrm{mg} 8$ hourly. Therapy of intravenous dexamethasone $8 \mathrm{mg} 8$ hourly was given adjunctively with antibiotics for suspected bacterial meningitis complications. Monotherapy with tablet levetiracetam $500 \mathrm{mg}$ two times per day along with tablet pyridoxine $50 \mathrm{mg}$ once daily was continued. Antibiotics and steroids were discontinued once CSF analysis did not show any evidence of bacterial meningitis. For her acute kidney injury, gentle hydration with intravenous normal saline at $75 \mathrm{~mL} /$ hour was continued. Her blood sugar levels were monitored and insulin Humalog sliding scale given accordingly. Desmopressin $0.1 \mathrm{mg}$ two times per day was also added due to her diagnosed diabetes insipidus.

\section{OUTCOME AND FOLLOW-UP}

The patient did not have any residual neurological sequelae. She became fully oriented, with complete resolution of her confusion and disorientation. She was discharged home 4 days later, on levetiracetam along with desmopressin and oral hypoglycaemics. Her isolation continued for a total of 10 days' duration after COVID-19 PCR positive test result. She followed up in internal medicine, neurology and endocrinology teleclinics 1 week later for her follow-up status. No repeat testing of the COVID-19 PCR swab was done. The patient continues to live comfortably and has resumed her daily routine. The patient has routinely followed-up in neurology clinics and has remained seizure-free since the index presentation.

\section{DISCUSSION}

SARS-CoV-2 virus belongs to the beta genus classification of the human Coronavirus family. The spike proteins of SARS-CoV-2 use ACE- 2 to bind to cells. The location of ACE- 2 receptors in the CNS has a significance with respect to COVID-19 encephalitis since expression in the cerebral cortex and brainstem has been observed. ${ }^{8}$

Different mechanisms have been postulated regarding the route of infiltration of the virus into the CNS. Neurological disease may be the consequence of cytokine-related injury, retrograde travel of the virus along the olfactory nerve, or the CNS vasculature being breached by direct binding to the ACE-2 receptors on endothelial cells of the blood-brain barrier. ${ }^{6}$

Neurological manifestations have previously been observed in other coronavirus infections, such as during the SARS-CoV and MERS (Middle East respiratory syndrome) outbreaks. Lau et al reported a case in 2004 where SARS-CoV-1 PCR was positive in the CSF of a patient presenting with generalised tonicclonic seizure. ${ }^{9}$ Similarly, Hung et al reported another patient with encephalopathy, seizures and presence of SARS-CoV RNA in CSF was also noted. ${ }^{10}$ MERS (2012) was also associated with severe neurological syndrome. Harthi et al delineated the case of three patients who developed neurological symptoms, two out of three patients' CSF sample analysis reported negative for MERS-CoV RT-PCR. ${ }^{11}$ Therefore, neurological manifestations to COVID-19 were not unanticipated.

Encephalitis can present with acute onset fever, vomiting, seizures and altered consciousness level. ${ }^{12}$ Ye et al ${ }^{13}$ reported a SARS-CoV-2 positive male patient in Wuhan who presented with decreased consciousness and confusion. Rare presentation of COVID-19 encephalitis, with catatonic syndrome as the initial presentation of the disease has also been reported. ${ }^{14}$

The UK national registry of patients with COVID-19 with neurological complications reported altered mental status in $31 \%$ of 125 patients, among these patients $13 \%$ presented with encephalopathy and encephalitis was observed in $6 \% .{ }^{15}$ BernardValnet $e \mathrm{al}^{16}$ also reported regarding a patient with COVID-19 presenting with tonic-clonic seizure. Similarly, our patient presented in a unique manner with generalised tonic-clonic seizures and loss of consciousness. Later, the patient tested positive for SARS-CoV-2 on her nasal swab. Physical evaluation of neurological symptoms is important and leads to a comprehensive differential diagnosis.

CSF analysis of our patient revealed pleocytosis $\left(15 / \mathrm{mm}^{3}\right)$ with a predominant $(95 \%)$ lymphocytic abundance leading to the diagnosis of viral encephalitis, presumably COVID-19 encephalitis. The Bio-Fire meningitis/encephalitis panel also reported negative for any microorganism. Huang et $a l^{17}$ and Kamal et $a l^{18}$ reported about patients admitted for encephalitis with a positive nasopharyngeal swab for SARS-CoV-2, to concomitantly have CSF to be positive for SARS-CoV-2 on RT-PCR. Our patient had a viral CSF picture but SARS-CoV-2 RT-PCR on the CSF sample could not be performed. CSF analysis of a large cohort of 30 patients with COVID-19 with neurological symptoms who underwent lumbar puncture showed negative RT-PCR results for SARS-CoV-2 in CSF. ${ }^{8}$

Our limitation was not being able to test the CSF for SARSCoV-2, as this facility is not available in our hospital. However, CSF SARS-CoV-2 RT-PCR is not necessary for diagnosis of COVID-19-associated encephalitis. Ye et $a l^{13}$ reported encephalitis associated with SARS-CoV-2 infection; the CSF analysis was within normal limits as well as negative for SARS-CoV-2 RT-PCR. A recent reported case discussed a COVID-19 positive patient with prior structural brain disease who developed seizures and was intubated, while his lumbar puncture was suggestive of viral meningitis. ${ }^{19}$ Although the definitive diagnosis of viral encephalitis requires CSF virus isolation, due to transient 
CSF viral shedding and low CSF titres, this can be difficult to assess. Another report described a case of COVID-19-associated encephalopathy, with lymphocytosis in CSF analysis and CSF PCR negative for SARS- CoV-2; this patient was successfully treated with intravenous immunoglobulin therapy (IVIG). ${ }^{20} \mathrm{In}$ contrast to this, our patient improved on conservative therapy with oral levetiracetam and pyridoxine. IVIG therapy would have been considered in case of severe COVID-19 infection or no improvement with conservative management; moreover, IVIG is an expensive therapy in a low-source country such as Pakistan.

Based on MRI and EEG findings, varied methods of diagnosing COVID-19 encephalitis have been reported in the literature. Vandervost ${ }^{21}$ et al reported a case with confirmed SARS-CoV-2 on nasopharyngeal testing and normal lumbar puncture findings; however, MRI brain showed asymmetric Fluid-attenuated inversion recovery (FLAIR) hyperintensity of the left medial temporal cortex associated with mild gyral expansion and this lead to the diagnosis of encephalitis associated with SARS-CoV-2. On the contrary, our patient had normal MRI, MRA and MRV brain findings. Langley et $a l^{22}$ reported a case of acute disseminated encephalomyelitis (ADEM) as a neurological sequelae of COVID-19 with characteristic brain MRI findings and CSF analysis. ${ }^{22}$

Furthermore, in a systematic review of EEG findings in patients with COVID-19 by Arun et al, ${ }^{23}$ common indications for EEG in patients with COVID-19 were altered mental status in 61.7\% and seizure-like activity or events in $31.2 \%$ patients. Abnormal EEG findings were reported in $88 \%$ of their subjects, ${ }^{23}$ while a meta-analysis also evidenced abnormal background activity and generalised slowing to be present in a large proportion of

\section{Patient's perspective}

I am very grateful to all the doctors and paramedical staff for my treatment. I have recovered completely, and I feel grateful to have received optimal medical care at the appropriate time. It was difficult to isolate myself in a room and to be away from my family. My young kids were also in quarantine, and immensely missed their mother. For quite some time after being discharged home from the hospital, I remained depressed and stayed quiet at home. I would ponder about how it all happened and how I contracted COVID-19. But it was my husband and sister, who really helped me get back to my daily routine. I feel blessed to have been given back life again. Additionally, I feel that the masses should practice precautionary measures for COVID-19; and help those affected by COVID-19.

\section{Learning points}

- Clinicians should maintain a high index of suspicion on neurological manifestations as initial presentation of COVID-19 during this pandemic; this presentation remains a unique entity.

- A simple and cost-effective test, electroencephalogram can be considered an essential tool in diagnosing COVID-19 encephalopathy.

- Conservative management of COVID-19-associated encephalopathy, with antiepileptic drugs as prophylaxis for generalised tonic seizures and supportive treatment can result in good outcomes. patients, that is, $96.1 \% .{ }^{24}$ The most common background abnormality noted in the systematic review was diffuse slowing as opposed to slow posterior dominant rhythm in the theta range in our patient and this was present in only 14 out of 617 patients. ${ }^{23}$ Arun $e a^{23}$ also determined that generalised rhythmic activity was seen in $5.2 \%$ of the cases in the systematic review of the periodic rhythmic EEG patterns of patients with COVID-19, and subsequently evidenced in our patients' EEG as well. However, absence of a control EEG to determine resolution of electroencephalographic changes over short-time period in our case was a limitation.

Contributors The contributors of this work include AFS for direct medical care and draft of the structure of the article; SS for drafting the article and literature review; TE for direct patient care, article editing and the submission process; and ZM for direct patient care, final approval of manuscript as well as being the most responsible physician. We are thankful to the patient for consenting to publish her case.

Funding The authors have not declared a specific grant for this research from any funding agency in the public, commercial or not-for-profit sectors.

\section{Competing interests None declared.}

Patient consent for publication Consent obtained directly from patient(s)

Provenance and peer review Not commissioned; externally peer reviewed.

Case reports provide a valuable learning resource for the scientific community and can indicate areas of interest for future research. They should not be used in isolation to guide treatment choices or public health policy.

\section{ORCID iD}

Aisha Fareed Siddiqui http://orcid.org/0000-0003-1571-2820

\section{REFERENCES}

1 World Health Organization. Weekly operational update on COVID-19. WHO, 2021

2 Ellul MA, Benjamin L, Singh B, et al. Neurological associations of COVID-19. Lancet Neurol 2020;19:767-83.

3 Mao L, Jin H, Wang M, et al. Neurologic manifestations of hospitalized patients with coronavirus disease 2019 in Wuhan, China. JAMA Neurol 2020:77:683.

4 Berger JR. COVID-19 and the nervous system. J Neurovirol 2020;26:143-8.

5 Whittaker A, Anson M, Harky A. Neurological manifestations of COVID-19: a systematic review and current update. Acta Neurol Scand 2020;142:14-22.

6 Bridwell R, Long B, Gottlieb M. Neurologic complications of COVID-19. Am J Emerg Med 2020;38:1549.e3-1549.e7

7 Graus F, Titulaer MJ, Balu R, et al. A clinical approach to diagnosis of autoimmune encephalitis. Lancet Neuro/ 2016;15:391-404

8 Neumann B, Schmidbauer ML, Dimitriadis K, et al. Cerebrospinal fluid findings in COVID-19 patients with neurological symptoms. J Neurol Sci 2020;418:117090.

9 Lau K, Yu W, Chu C. Infection by SARS coronavirus. Emerg Infect Dis 2004;10:2-4.

10 Hung ECW, Chim SSC, Chan PKS, et al. Detection of SARS coronavirus RNA in the cerebrospinal fluid of a patient with severe acute respiratory syndrome. Clin Chem 2003;49:2108-9.

11 Arabi YM, Harthi A, Hussein J, et al. Severe neurologic syndrome associated with middle East respiratory syndrome corona virus (MERS-CoV). Infection 2015;43:495-501.

12 Ellul M, Solomon T. Acute encephalitis - diagnosis and management. Clin Med 2018;18:155-9.

13 Ye M, Ren Y, Lv T. Encephalitis as a clinical manifestation of COVID-19. Brain Behav Immun 2020;88:945-6.

14 Vazquez-Guevara D, Badial-Ochoa S, Caceres-Rajo KM, et al. Catatonic syndrome as the presentation of encephalitis in association with COVID-19. BMJ Case Rep 2021; 14:e240550.

15 Varatharaj A, Thomas N, Ellul MA, et al. Neurological and neuropsychiatric complications of COVID-19 in 153 patients: a UK-wide surveillance study. Lancet Psychiatry 2020;7:875-82

16 Bernard-Valnet R, Pizzarotti B, Anichini A, et al. Two patients with acute meningoencephalitis concomitant with SARS-CoV-2 infection. Eur J Neurol 2020;27:e43-4.

17 Huang YH, Jiang D, Huang JT. SARS-CoV-2 detected in cerebrospinal fluid by PCR in a case of COVID-19 encephalitis. Brain Behav Immun 2020;87:149.

18 Kamal YM, Abdelmaiid Y, Al Madani AAR. Cerebrospinal fluid confirmed COVID-19associated encephalitis treated successfully. BMJ Case Rep 2020;13:e237378. 
19 Jalil BA, ljaz M, Khan AM, et al. A young man presenting with encephalopathy and seizures secondary to SARS-CoV-2. BMJ Case Rep 2021;14:e240576.

20 El-Zein RS, Cardinali S, Murphy C, et al. COVID-19-associated meningoencephalitis treated with intravenous immunoglobulin. BMJ Case Rep 2020;13:e237364.

21 Vandervorst F, Guldolf K, Peeters I, et al. Encephalitis associated with the SARS-CoV-2 virus: a case report. Interdiscip Neurosurg 2020;22:100821
22 Langley L, Zeicu C, Whitton L, et al. Acute disseminated encephalomyelitis (ADEM) associated with COVID-19. BMJ Case Rep 2020;13:e239597.

23 Raj A, Haneef Z. Seizure : European Journal of Epilepsy Systematic review of EEG findings in 617 patients diagnosed with. Seizure Eur J Epilepsy 2020;83:234-41.

24 Kubota T, Gajera PK, Kuroda N. Meta-Analysis of EEG findings in patients with COVID-19. Epilepsy Behav 2021;115:107682.

Copyright 2022 BMJ Publishing Group. All rights reserved. For permission to reuse any of this content visit https://www.bmj.com/company/products-services/rights-and-licensing/permissions/

BMJ Case Report Fellows may re-use this article for personal use and teaching without any further permission.

Become a Fellow of BMJ Case Reports today and you can:

- Submit as many cases as you like

- Enjoy fast sympathetic peer review and rapid publication of accepted articles

- Access all the published articles

Re-use any of the published material for personal use and teaching without further permission

Customer Service

If you have any further queries about your subscription, please contact our customer services team on +44 (0) 2071111105 or via email at support@bmj.com.

Visit casereports.bmj.com for more articles like this and to become a Fellow 